\title{
KINERJA PEGAWAI DALAM MENDUKUNG PELAKSANAAN TUGAS POKOK BADAN PENGELOLA KEUANGAN DAN ASSET DAERAH KABUPATEN JENEPONTO
}

\author{
Irnawati Sanre Gunawan ${ }^{1}$, Nuryanti Mustari ${ }^{2}$, Jaelan Usman ${ }^{3}$ \\ Universitas Muhammadiyah Makassar \\ irnagunawan79@gmail.com
}

\begin{abstract}
Abstrak
Penelitian ini bertujuan untuk mengetauhui bagaimana Kinerja dan upaya meningkatkan kinerja pegawai dalam mendukung pelaksanaan tugas pokok badan pengelola keuagan dan asset daerah kabupaten jeneponto. Metode yang digunakan dalam penelitian ini adalah deskriptif kualitatif dengan menggunakan istrumen observasi, wawancara, dan dokumentasi. Kemudian teknik analisa data melalui reduksi data, penyajian data, dan penarikan kesimpulan. Hasil penelitian menunjukkan bahwa; (1) Kualitas kerja (2) Kerjasama; (3) Loyalitas.(4) Tanggung jawab kemudian dalam upaya meningkatkan kinerja pegawai yaitu; 1). Kemampuan Kinerja Pegawai atas Laporan Keuangan (CaLK) mengacu pada Standar, yaitu; mampu memahami Tujuan Sistem Akuntansi Pemerintah Daerah (2) Peningkatan Kompetensi Pegawai, yaitu; meningkatakan kompetensi pegawai yang dilakukan dapat memperdalam dan memperluas kemampuan kerja, dan, SKPD harus memiliki SDM yang berkompeten, yang didukung dengan latar belakang pendidikan yang sesuai, sering mengikuti pendidikan dan pelatihan serta mempunyai pengalaman di bagian keuangan. (3) Tunjangan Kesejahteraan Pegawai, yaitu; memberikan tambahan penghasilan kepada pegawai negeri sipil daerah berdasarkan pertimbangan yang obyektif dengan memperhatikan kemampuan keuangan daerah dan memperoleh persetujuan DPRD.
\end{abstract}

Kata Kunci : Kinerja, pegawai, pengelola keuagan dan asset daerah

\begin{abstract}
This study aims to find out how the performance and efforts to improve employee performance in supporting the implementation of the main tasks of the Jeneponto Regency regional financial and asset management agency. The method used in this research is descriptive qualitative by using instruments of observation, interviews, and documentation. Then data analysis techniques through data reduction, data presentation, and drawing conclusions. The results showed that; (1) Quality of work (2) Cooperation; (3) Loyalty. (4) Later responsibilities in an effort to improve employee performance are; 1). Employee Performance Capability on Financial Statements (CaLK) refers to the Standards, namely; able to understand the Objectives of the Regional Government Accounting System (2) Employee Competence Improvement, namely; improving employee competence can deepen and broaden work abilities, and SKPD must have competent human resources, supported by appropriate educational backgrounds, often attend education and training and have experience in the finance department. (3) Employee Welfare Allowance, namely; provide additional income to regional civil servants based on objective considerations by taking into account the regional financial capacity and obtaining approval from the DPRD.
\end{abstract}

Keywords: Performance, employees, regional financial and asset managers

\section{PENDAHULUAN}

Kinerja pemerintah daerah saat ini sangat menjadi sorotan publik karena dianggap belum mampu menunjukkan hasil yang baik untuk dirasakan oleh masyarakat. Masyarakat menuntut pemerintah untuk mempunyai kinerja yang baik dalam melaksanakan tugas dan tanggung jawabnya sebagai perwujudan konsep otonomi daerah sesuai dengan Undang-undang No. 32 Tahun 2004 tentang Pemerintah Daerah.

Mardiasmo (2004) mengatakan bahwa kinerja merupakan kemampuan kerja yang ditunjukkan dengan hasil kinerja yang baik. Pemerintah dikatakan mempunyai kinerja yang baik apabila mampu mengelola pemerintahan dengan baik sehingga dapat 
memberikan kesejahteraan kepada masyarakatnya secara keseluruhan. Kinerja yang baik juga tercermin dari pengelolaan keuangan yang baik.

Pengelolaan keuangan dan asset daerah di era reformasi saat ini mengalami berbagai perubahan regulasi dari waktu ke waktu. Perubahan tersebut merupakan rangkaian bagaimana suatu Pemerintah Daerah dapat menciptakan good governance dan clean government dengan melakukan tata kelola keuangan pemerintahan yang baik. Keberhasilan dari suatu pembangunan di daerah tidak terlepas dari aspek pengelolaan keuangan daerah yang dikelola dengan manajemen yang baik pula. Kinerja pemerintah daerah saat ini sangat menjadi sorotan publik karena dianggap belum mampu menunjukkan hasil yang baik untuk dirasakan oleh masyarakat.

Menghadapi perkembangan dunia yang demikian pesat, dan seiring dengan derasnya aspirasi reformasi didalam negeri, maka peranan penyelenggaraan pemerintahan dan administrasi publik yang baik menjadi semakin penting. Dalam menghadapi perubahan perlu kehati-hatian untuk dapat menyesuaikan diri dengan perkembangan sekaligus menjaga kelangsungan organisasi agar dapat bertahan hidup. Peranan sumber daya manusia merupakan tokoh sentral dalam organisasi. Hal tersebut dengan didasari bahwa yang kita ketahui sumber daya manusia merupakan modal atau aset bagi institusi atau organisasi.

Mansusia dipandang sebagai sumber daya penggerak dari suatu organisasi termasuk penggerak dari sumber daya lainnya baik itu sumber daya alam maupun teknologi. Hal ini merupakan suatu penegasan kembali terhadap falsafah "Man behind the gun". Roda organisasi sangat tergantung pada perilaku-perilau manusia yang bekerja di dalamnya. Dengan kata lain, keberhasilan organisasi dalam meningkatkan manajemen menjadi efektif dan efisien tidak terlepas dari peran sumber daya manusia (SDM). Hal ini menegaskan bahwa SDM merupakan aset termahal dan terpenting bagi organisasi untuk mencapai tujuannya.

Sebagai unsur organisasi, manusia memiliki peran yang sangat penting dalam menjalankan fungsinya dalam rangka kemajuan organisasi. Potensi setiap individu yang ada dalam organisasi harus dapat dimanfaatkan sebaik-baiknya sehingga mampu memberikan hasil yang maksimal. Dimana keberhasilan organisasi sangat tergantung pada peran manusia didalamnya karena manusia sebagai sumber daya yang potensial dan merupakan sumber kekuatan untuk menggerakkan roda aktivitas organisasi.

Sumber daya manusia harus diarahkan dan dikoordinasikan untuk menghasilkan konstribusi terbaik bagi organisasi, sehingga apa yang menjadi tujuan organisasi dapat terwujud. Setiap organisasi berupaya untuk mendapatkan pegawai yang terlibat dalam kegiatan organisasi agar memberikan hasil berupa prestasi kerja dengan dilihat dalam bentuk produktivitas kerja setinggi mungkin untuk mewujudkan tujuan yang telah ditetapkan sebelumnya. Adapun beberapa faktor yang berhubungan dengan kinerja dan produktivitas diantaranya semangat kerja, tingkat pendidikan, keterampilan, sikap dan etika, motivasi, iklim kerja, teknologi, sarana produksi, kesempatan kerja dan kesempatan berprestasi, dan disiplin kerja.

Setiap organisasi dalam melaksanakan programnya selalu diarahkan untuk mencapai tujuannya. Salah satu faktor yang menjadi kriteria untuk mencapai kelancaran tujuan suatu organisasi adalah mengidentifikasi dan mengukur kinerja pegawainya. Organisasi merupakan suatu kesatuan kompleks yang berusaha mengalokasikan sumber daya manusia secara penuh demi tercapainya suatu tujuan. Apabila suatu organisasi mampu mencapai tujuan yang telah ditetapkan, maka dapat dikatakan bahwa organisasi tersebut efektif.

Selain memperhatikan faktor Sumber Daya Manusia yang unggul hal lain yang perlu diperhatikan juga yaitu faktor yang berhubungan dengan kinerja untuk mengukur produktivitas kerja yang ada seperti semangat kerja yang dibangun harus berdasarkan situas kondisi budaya yang ada dan harus dibangun dengan semangat motivasi yang positif, artinya tidak bertentangan dengan lingkungan dimana para pegawai melaksanakan pekerjaannya dan tidak bertentangan dengan semangat kerja individual. Jika semangat kerja dapat terbangun maka lingkungan kerjapun akan kondusif dan berpengaruh langsung terhadap kinerja yang ada. 
Tingkat pendidikan berperan dalam membentuk kinerja dan produktivitas yang ada. Semakin tinggi tingkat pendidikan seorang pegawai semakin luas juga pola pikir pegawai dalam penyelesaian pekerjaan sehingga dapat menyelesaikan pekerjaan dengan tepat bahkan dapat berinovasi dalam lingkungan kerjanya. Tingkat pendidikan pun harus disertakan dengan kemampuan keterampilan yang harus dimiliki oleh seseorang karena dianggap penting guna menciptakan kreativitas dalam bekerja. Jika seorang pegawai tersebut kreatif dan memiliki tingkat pendidikan yang tinggi otomatis akan sangat berpengaruh dan akan sangat dibutuhkan sekali oleh organisasi.

Sikap dan etika pun harus diperhatikan dalam membentuk kinerja organisasi yang unggul. Tanpa sikap dan etika yang baik seseorang dengan latar belakang pendidikan yang tinggi dan keterampilan yang unggul akan sia-sia, artinya akan membentuk moral individu seorang pegawai menjadi buruk. Seperti kita lihat di media masa, banyak sekali seorang pegawai dengan latar belakang sarjana dan magister terjerumus kedalam sel tahanan penjara. Hal tersebut sebagai contoh bahwa sikap dan etika tidak dimiliki oleh individu tersebut.

Hal yang teramat penting dalam mendapatkan pegawai yang terlibat dalam kegiatan organisasi agar memberikan hasil berupa prestasi kerja yang baik yaitu motivasi kerja. Motivasi kerja harus didukung peran serta pimpinan untuk membentuk karakter individu pegawai lebih unggul. Pengawasan dan pembinaan dalam rangka motivasi sangat perlu sekali dibutuhkan dan diaplikasikan dalam tubuh seorang pimpinan sebagai tonggak pemberi motivasi kepada bawahannya. Motivasi yang terbangun akan memberikan dorongan pegawai untuk bekerja lebih baik lagi. Hubungan kedekatan pun antara pimpinan dengan pegawai harus terbangun harmonis.

Semua faktor yang dibicarakan di atas baik itu semangat kerja, tingkat pendidikan, keterampilan, sikap dan etika, dan motivasi akan sangat berpengaruh sekali dalam iklim kerja. Iklim kerja yang kondusif, nyaman, dan tertib akan membawa dampak bagi organisasi mampu berjalan dengan baik.

Hal lain yang tidak ketinggalan yang harus dijadikan perhatian untuk membangun organisasi yaitu teknologi dan sarana produksi yang mendukung, karena kita lihat jika pegawai tanpa didukung oleh teknologi dan sarana prasarana produksi kerja yang baik akan stagnan dan tidak dapat melakukan pekerjaan. Begitu pun juga harus didukung dengan penerapan teknologi terkini sesuai dengan perkembangan zaman.

Faktor selanjutnya yang perlu diperhatikan juga yaitu kesempatan yang sama dapat perolehan hak yang adil sesama pegawai yang diberikan oleh pimpinan, yaitu kesempatan kerja dan kesempatan berprestasi. Semua pegawai mempunyai hak untuk bekerja dan ingin mencapai prestasi, hal itulah yang tidak boleh dibatasi dan tugas pimpinan harus peka terhadap hak-hak setiap pegawai.

Kurang lengkap jika kita ingin menciptakan organisasi yang baik dengan didukung oleh kinerja pegawai yang baik tanpa memperhatikan faktor disiplin. Disiplin pegawai faktor penentu dalam membentuk karakter kualitas individu yang unggul. Jika disiplin pegawai terbentuk tujuan organisasi pun akan tercapai karena semua pekerjaan dilakukan dengan tepat dan dilakukan dengan penegakan disiplin yang ada.

Kinerja pegawai pada dasarnya adalah apa yang dilakukan atau tidak dilakukan. Kinerja pegawai mempengaruhi seberapa banyak mereka memberikan kontribusi kepada organisasi. Setiap pekerjaan memiliki kriteria pekerjaan yang spesifik, atau dimensi kerja yang mengidentifikasi elemen-elemen yang paling penting dari suatu pekerjaan. Dinas Pendapatan dan Keuangan Daerah mempunyai tupoksi sebagai melaksanakan urusan pemerintah daerah berdasarkan asas otonomi daerah dan tugas pembantuan di bidang pendapatan dan pengelolaan keuangan daerah.

Dari hasil observasi awal berdasarkan pengamatan peneliti di Badan Pengelolaan Keuangan dan Asset Daerah (BPKAD) Kabupaten Jeneponto terdapat beberapa masalah mengenai kinerja pegawai. Pertama, masih terdapat beberapa pegawai yang kurang disiplin. Hal ini terlihat dari data absensi pegawai yang merupakan salah satu unsur yang dapat menunjang profesionalisme kinerja pegawai. Absen pada pagi hari terlihat pada saat apel pagi. Setiap pelaksanaan apel pagi, ada saja beberapa pegawai yang tidak mengikuti kewajiban untuk apel pagi dan terlambat untuk absen pagi. dan biasanya juga 
sama halnya dengan absen pagi, absen sore juga ada saja pegawai yang tidak melakukan absen sore. Kedua, masih ada pegawai yang tidak patuh terhadap aturan dan perintah telah ditentukan. Hal ini menunjukan bahwa tingkat kesadaran dan inisiatif pegawai masih rendah. Jika seorang pegawai memiliki inisiatif untuk tunduk dan mengikuti tata tertib yang ada maka kinerja akan lebih baik tanpa adanya paksaan. Dari pengamatan penulis melhat bahwa, masih adanya pegawai yang tidak patuh terhadap perintah yang diberikan pimpinan. Salah satu contoh misalanya masih adanya pegawai yang tidak melaksanakan atau merespon pekerjaan yang diberikan oleh pimpinan BPKAD, pegawai tidak langsung dengan cepat mengerjakannya melainkan menunggu perintah, tidak ada inisiatif sendiri untuk menegerjakannya.

Masalah ini menunjukan lemahnya pengawasan yang dilakukan oleh pegawai padahal Undang-Undang nomor 5 Tahun 2014 tentang Aparatur Sipil Negara pasal 23 disebutkan, bahwa Aparatur Sipil Negara wajib melaksanakan tugas kedinasan dengan penuh pengabdian, kejujuran, kesadaran, dan tanggung jawab. Selain mengenai inisiatif dalam menjalankan disiplin, terlihat juga di Dinas BPKAD Kabupaten Jeneponto tindakan inisiatf untuk melaksanakan pekerjaan masih rendah, seperti halnya para pegawai harus melaksanakan pekerjaannya berdasarkan perintah atasan tanpa adanya inisiatif individu. Ketiga lemahnya pengawasan langsung oleh pimpinan terkait pelaksanaan kinerja pegawai sehingga produktivitas kerja cenderung rendah, Lemahnya pengawasan berhubungan langsung dengan motivasi yang diberikan, karena bentuk pengawasan tergambar dari pemberian motivasi yang ada. Jika pengawasan di di (BPKAD) Badan Pengelola Keuangan dan Asset Daerah Kabupaten Jeneponto dapat terbangun dengan berarti bahwa motivasi yang ada telah dilaksanakan. Para pegawai melaksanakan pekerjaan dengan bebas tanpa adanya bimbingan atau motivasi dengan begitu terlihat pengawasan yang ada tidak terbangun. Berdasarkan penelitian sebelunya oleh Adinata (2017), mengenai anilisis faktor-faktor yang mempengaruhi kinerja keuagan daerah yang slalu mengalami regulasi dari waktu kewaktu, sehingga untuk memaksimalkan kinerja yang baik maka perlu regulasi yang jelas seingga dapat memberikan kesejahteraan masyarakat secara luas.

\section{TINJAUAN PUSTAKA}

Kinerja dalam organisasi merupakan jawaban dari berhasil atau tidaknya tujuan organisasi yang telah ditetapkan. Para atasan atau manajer sering tidak memperhatikan kecuali sudah amat buruk atau segala sesuatu jadi serba salah. Terlalu sering manajer tidak mengetahui betapa buruknya kinerja telah merosot sehingga perusahaan/ instansi menghadapi krisis yang serius. Kesan-kesan buruk organisasi yang mendalam berakibat dan mengabaikan tanda-tanda peringatan adanya kinerja yang merosot.

Menurut Keban dalam Sukardi, (2005:242) mendefinisikan kinerja sebagai tingkat pencapaian hasil atau dengan kata lain, kinerja merupakan tingkat pencapaian suatu organisasi. Kinerja keuangan berarti suatu yang dicapai, prestasi yang diperlihatkan, kemampuan kerja pada bidang koperasi. Sedangkan Ambar Teguh Sulistiyani (2003:223), mengatakan bahwa "Kinerja seseorang merupakan kombinasi dari kemampuan, usaha dan kesempatan yang dapat dinilai dari hasil kerjanya". Lebih lanjut Hasibuan (2008:34) mengemukakan "Kinerja (prestasi kerja) adalah suatu hasil kerja yang dicapai seseorang dalam melaksanakan tugastugas yang dibebankan kepadanya yang didasarkan atas kecakapan, pengalaman dan kesungguhan serta waktu".

Kinerja merupakan suatu kondisi yang harus diketahui dan dikonfirmasikan kepada pihak tertentu untuk mengetahui tingkat pencapaian hasil suatu instansi dihubungkan dengan visi yang diemban suatu organisasi atau perusahaan serta mengetahui dampak positif dan negatif dari suatu kebijakan operasional. Mink (2003:76) mengemukakan pendapatnya bahwa individu yang memiliki kinerja yang tinggi memiliki beberapa karakteristik, yaitu diantaranya :

1. Berorientasi pada prestasi,

2. Memiliki percaya diri,

3. Berperngendalian diri, dan

4. Kompetensi

Menurut Rue dan Byars yang disunting Edy Suandi Hamid dan Sobirin Malian (2004:45) mengemukakan bahwa:“Kinerja 
dapat didefinisikan sebagai pencapaian hasil atau "the degree of accomplishment" tingkat pencapaian organisasi. Selanjutnya, hasil kerja seseorang dapat dinilai dengan standar yang telah ditentukan, sehingga akan dapat diketahui sejauhmana tingkat kinerjanya dengan membandingkan antara hasil yang dicapai dengan standar yang ada".

Lebih lanjut Suyadi Prawirosentono (2004:2),mengatakan bahwa: "Kinerja merupakan hasil kerja yang dapat dicapai oleh seseorang atau sekelompok orang dalam suatu organisasi, sesuai dengan wewenang dan tanggung jawab masing-masing dalam rangka upaya mencapai tujuan berkaitan kuat terhadap tujuan-tujuan strategik organisasi".

Sedangkan kinerja menurut Robbins adalah sebagai fungsi dari interaksi antara kemampuan (ability), motivasi (motivation) dan keinginan (obsetion). Selanjutnya Robbins memberikan arti kinerja adalah tingkat pencapaian tujuan. Kinerja organisasi sangat ditentukan oleh unsur pegawainya karena itu dalam mengukur kinerja suatu organisasi sebaiknya diukur dalam tampilan kerja dari pegawainya. Menurut Mitchel sebagaimana dikutip oleh Stephen P. Robbins (2009), menyebutkan aspek-aspek yang meliputi kinerja yang dapat dijadikan ukuran kinerja seseorang, yaitu :

\section{Kualitas kerja}

Kualitas kerja menunjukkan mutu seorang pegawai dalam melaksanakan tugastugasnya meliputi ketepatan, kelengkapan, dan kerapian. kualitas kerja secara sederhana sebagai kesesuaian untuk digunakan. kualitas kerja adalah kesesuaian dengan kebutuhan yang meliputi availability, delivery, realibility, maintainability, dan cost effectivenes.

\section{Kuantitas kerja}

Kuantitas kerja adalah jumlah kerja yang dilaksanakan oleh seseorang pegawai dalam suatu periode tertentu. Hal ini dapat dilihat dari hasil kerja pegawai dalam kerja penggunaan waktu tertentu dan kecepatan dalam menyelesaikan tugas dan tanggung jawabnya.

Menurut Wungu dan Brotoharsojo (2003:56) bahwa Quantity (kuantitas) adalah segala bentuk satuan ukuran yang terkait dengan jumlah hasil kerja dan dinyatakan dalam ukuran angka atau yang dapat dipadankan dengan angka. Sedangkan menurut Wilson dan Heyyel (1987:101) mengatakan bahwa kuantitas kerja adalah jumlah kerja yang dilaksanakan oleh seseorang pegawai dalam suatu periode tertentu. Hal ini dapat dilihat dari hasil kerja pegawai dalam kerja penggunaan waktu tertentu dan kecepatan dalam menyelesaikan tugas dan tanggung jawabnya. Dengan demikian kuantitas kerja dapat dilihat dari jumlah kerja dan penggunaan waktu. Jumlah kerja adalah banyaknya tugas pekerjaanya, dapat dikerjakan. Penggunaan waktu adalah banyaknya waktu yang digunakan dalam menyelesaikan tugas dan pekerjaan.

\section{Kerjasama}

Kerjasama akan ada jika ada minimal dua orang/ pihak yang melakukan kesepakatan. Oleh karena itu, sukses tidaknya kerjasama tersebut ditentukan oleh peran dari kedua orang atau kedua pihak yang bekerjasama tersebut. Kerjasama adalah sebuah sistem pekerjaan yang kerjakan oleh dua orang atau lebih untuk mendapatkan tujuan yang direncanakan bersama. Kerjasama dalam tim kerja menjadi sebuah kebutuhan dalam mewujudkan keberhasilan kinerja dan prestasi kerja.

Menurut West (2002:39), bahwa kerjasama secara berkelompok mengarah pada efisiensi dan efektivitas yang lebih baik. Hal ini sangat berbeda dengan kerja yang dilaksanakan oleh perorangan. Davis dalam Dewi (2006:76), bahwa kerjasama adalah keterlibatan mental dan emosional orang dalam situasi kelompok yang mendorong mereka untuk memberikan kontribusi dan tanggung jawab dalam mencapai tujuan kelompok. Kontribusi tiap-tiap individu dapat menjadi sebuah kekuatan yang terintegrasi. Individu dikatakan bekerjasama jika upayaupaya dari setiap individu tersebut secara sistematis terintegrasi untuk mencapai tujuan bersama. Dalam mencapai tujuan bersama, kerjasama memberikan manfaat yang besar bagi kerja tim.

\section{Inisiatif}

Inisiatif adalah dorongan untuk mengidentifikasi masalah atau peluang dan mampu mengambil tindakan nyata untuk menyelesaikan masalah atau menangkap peluang. inisiatif adalah melakukan hal yang 
benar tanpa diberitahu. penerjemahan imaginasi menjadi perbuatan (action). Inisiatif terbagi menjadi 5 tingkat yaitu lakukan saja, bertindak sekarang dan minta maaf, minta izin, mencari suara terbanyak, dan menunggu disuruh.

\section{Kepemimpinan}

Kepemimpinan adalah proses mempengaruhi atau memberi contoh oleh pemimpin kepada pengikutnya dalam upaya mencapai tujuan organisasi. Tead; Terry; Hoyt dalam Kartono, (2003:24) Kepemimpinan yaitu kegiatan atau seni mempengaruhi orang lain agar mau bekerjasama yang didasarkan pada kemampuan orang tersebut untuk membimbing orang lain dalam mencapai tujuan- tujuan yang diinginkan kelompok.

Menurut Young dalam Kartono, (2003:25) Kepemimpinan yaitu bentuk dominasi yang didasari atas kemampuan pribadi yang sanggup mendorong atau mengajak orang lain untuk berbuat sesuatu yang berdasarkan penerimaan oleh kelompoknya, dan memiliki keahlian khusus yang tepat bagi situasi yang khusus. Moejiono (2002:12) memandang bahwa leadership tersebut sebenarnya sebagai akibat pengaruh satu arah, karena pemimpin mungkin memiliki kualitas- kualitas tertentu yang membedakan dirinya dengan pengikutnya. Dari beberapa definisi di atas dapat disimpulkan bahwa kepemimpnan merupakan kemampuan mempengaruhi orang lain, bawahan atau kelompok, kemampuan mengarahkan tingkah laku bawahan atau kelompok, memiliki kemampuan atau keahlian khusus dalam bidang yang diinginkan oleh kelompoknya, untuk mencapai tujuan organisasi atau kelompok.

\section{Loyalitas}

Loyalitas erat kaitannya kesetiaan, loyalitas memegang peranan penting dalam jalannya organisasi. Loyalitas sebagai kemauan untuk terus mendukung sebuah organisasi dalam jangka panjang, membeli dan menggunakan produk dan jasanya atas dasar rasa suka yang ekslusif dan secara sukarela merekomendasikan produk perusahaan pada para kerabatnya.

Loyalitas karyawan kepada organisasi dipandang dari dua segi. Pertama, yaitu loyalitas kepada perusahaan sebagai suatu sikap (attiludinal commitment). Kedua, loyalitas kepada organisasi sebagai suatu perilaku (behavioral commitment). Komitmen karyawan terhadap organisasi melibatkan tiga sikap, yaitu identifikasi dengan tujuan organisasi, perasaan keterlibatan dalam tugastugas organisasi, dan perasaan loyalitas terhadap organisasi.

\section{Tanggung Jawab}

Tanggung jawab adalah sifat terpuji yang mendasar dalam diri manusia. Ridwan Halim (2001:94) mendefinisikan tanggung jawab sebagai suatu akibat lebih lanjut dari pelaksanaan peranan, baik peranan itu merupakan hak maupun kewajiban ataupun kekuasaan. Secara umum tanggung jawab diartikan sebagai kewajiban untuk melakukan sesuatu atau berperilaku menurut cara tertentu. berpendapat bahwa tanggung jawab bersumber atau lahir atas penggunaan fasilitas dalam penerapan kemampuan tiap orang untuk menggunakan hak atau melaksanakan kewajibannya

\section{METODE}

Penelitian yang digunakan dalam penelitian ini adalah pendekatan kualitatif, Pendekatan kulaitatif dipilih karena dapat digunakan untuk mengungkap dan memahami sesuatu di balik fenomena yang belum diketahui. Selain itu, metode kualitatif dapat memberi rincian yang kompleks tentang fenomena yang sulit diungkapkan oleh metode kuantitatif. (Sugiyono, 2010).

Teknik analisis data dalam penelitian ini menggunakan model Miles dan Huberman yang mengemukakan bahwa aktifitas dalam analisis data kualitatif dilakukan secara interaktif dan berlangsung secara terus menerus dan sampai tuntas, sehingga datanya sudah jenuh. Aktifitas dalam analisis data, yaitu data reduction, data display, dan conclusion drawing/verification. seluruh data dan informasi yang bersumber dari data primer dan sekunder dengan teknik wawancara dan Penelitian ini di lakukan pada Badan Pengelola Keuangan dan Asset Daerah (BPKAD) Kabupaten Jeneponto.

\section{HASIL DAN PEMBAHASAN}


Peraturan Pemerintah (PP) No. 58 Tahun 2005 tentang Pengelolaan Keuangan Daerah yang ditindaklanjuti dengan Peraturan Menteri Dalam Negeri (Permendagri) No. 13 Tahun 2006 tentang Pedoman Pengelolaan Keuangan Daerah, dan telah diubah lagi dengan Permendagri No. 21 Tahun 2011 tentang Perubahan kedua atas Permendagri No. 13 Tahun 2006 tentang Pedoman Pengelolaan Keuangan Daerah. Perubahan yang sangat mendasar dalam peraturan tersebut adalah perubahan sistem akuntansi dan pengelolaan keuangan yang sebelumnya tersentralisasi pada dinas/badan/biro/bagian keuangan menjadi terdesentralisasi disetiap Satuan Kerja Perangkat Daerah (SKPD) dimana SKPD juga berkewajiban untuk membuat laporan keuangan SKPD. Dalam hal ini, SKPD dituntut untuk mampu menerapkan perubahan peraturan pengelolaan keuangan tersebut, agar peraturan yang telah ditetapkan tersebut mampu diimplementasikan dengan baik, SKPD dituntut untuk mempunyai kapasitas sumber daya manusia (SDM) yang baik, yang memiliki kinerja yang baik, khususnya dalam pengelolaan keuangan.

Masalah kinerja pegwai kabupaten jeneponto tentu tidak terlepas dari proses, hasil dan daya guna, dalam hal ini kinerja atau prestasi kerja merupakan hasil kerja secara kualitas dan kuantitas yang dicapai oleh pegawai dalam Mendukung Pelaksanaan Tugas Pokok Badan Pengelola Keuangan dan Asset Daerah Kabupaten Jeneponto, dalam melaksanakan tugasnya sesuai dengan tangung jawab yang diberikan kepadanya. Apabila kinerja di definisikan sebagai pencapaian hasil atau tingkat pencapaian tingkat organisasi, dan kinerja disebut sebagai performance yang memiliki arti suatu hasil kerja yang dapat dicapai oleh seseorang pegawai atau sekelompok orang dalam suatu organisasi sesuai dengan wewenang dan tanggung jawab masing-masing dalam rangka mencapai tujuan organisasi secara legal, tidak melanggar hukum dan sesuai dengan moral maupun etika. Untuk lebih jelasnya Kinerja Pegawai dalam Mendukung Pelaksanaan Tugas Pokok Badan Pengelola Keuangan dan Asset Daerah Kabupaten Jeneponto dapat kita lihat pembahasan sebagai berikut: $\begin{array}{ccc}\text { Keberhasilan } & \text { dalam pengelolaan } \\ \text { keuangan sangat ditentukan oleh }\end{array}$ kemampuan atau kompetensi para pegawai atau kualitas kerja Pegawai dalam Mendukung Pelaksanaan Tugas Pokok Badan Pengelola Keuangan dan Asset Daerah yang dapat dilihat sejauh mana mutu seorang pegawai dalam melaksanakan tugas-tugasnya menyelesaikan tugas dan tanggung jawabnya tepat waktu.

Kualitas pegawai di Dinas Pengelolaan Keuangan dan Asset Daerah kabupaten jeneponto masih kurang maksimal, hal ini dilihat berdasarkan kualifikasi para pegawai yang belum sesuai dengan jabatan yang diduduki serta kurangnya kemampuan maupun penguasaan teknologi yang ada. Kuantitas Pekerjaan di Bidang Aset Daerah adalah belum tercapainya target pekerjaan dikarenakan jumlah pekerjaan yang banyak yang tidak diimbangi dengan kompetensi pegawainya. Dalam hal ini seharusnya jumlah SDM yang ada bukan dijadikan alasan dalam ketidak tercapaian target yang ditetapkan karena apabila SDM yang ada sudah sesuai dengan kompetensinya maka walaupun pekerjaan banyak tetap dapat ditangani. Sehingga disini kuantitas pekerjaan yang dapat dicapai masih belum sesuai dengan target yang ditetapkan/ masih kurang maksimal.

\section{Kerjasama}

Kerjasama adalah sebuah sistem pekerjaan yang di kerjakan oleh dua orang atau lebih untuk mendapatkan tujuan yang direncanakan bersama. Kerjasama dalam tim kerja menjadi sebuah kebutuhan dalam mewujudkan keberhasilan kinerja dan prestasi kerja kerjasama yang dilakukan oleh Pegawai dalam Mendukung Pelaksanaan Tugas Pokok Badan Pengelola Keuangan dan Asset Daerah Jeneponto adalah keterlibatan mental dan emosional orang dalam situasi kelompok yang mendorong mereka untuk memberikan kontribusi dan tanggung jawab dalam mencapai tujuan kelompok. Kontribusi tiaptiap individu dapat menjadi sebuah kekuatan yang terintegrasi. Individu dikatakan bekerjasama jika upaya-upaya dari setiap individu tersebut secara sistematis terintegrasi untuk mencapai tujuan bersama. Dalam mencapai tujuan

\section{Kualitas kerja}


Pegawai bekerjasama dengan baik dalam Mendukung Pelaksanaan Tugas Pokok Badan Pengelola Keuangan dan Asset Daerah Kabupaten Jeneponto sementara dari pengamatan penulis melihat bahwa biasanya lemahnya kerjasama yang dilakukan baik antara pimpinan dengan bawahan dan antara sesama pegawai dalam organisasi dapat menimbulkan lingkungan kerja yang individualism.

\section{Loyalitas}

loyalitas pegawai kepada organisasi pemerintahan dipandang dari dua segi. Pertama, yaitu loyalitas kepada tempat instanasi dimana seorang pegawai bekerja sebagai suatu sikap (attiludinal commitment). Kedua, loyalitas kepada organisasi sebagai suatu perilaku (behavioral commitment). Komitmen pegawai terhadap instansi melibatkan tiga sikap, yaitu identifikasi dengan tujuan organisasi, perasaan keterlibatan dalam tugas-tugas organisasi, dan perasaan loyalitas terhadap organisasi

Pengamatan penulis menambahkan bahwa selain loyalitas pegawai Pengelolaan keuangan yang baik juga dapat terlihat dari pemahaman pengelola keuangan mengenai Sistem Akuntansi Pemerintah Daerah (SAPD) yang merupakan bagian dari pengelolaan keuangan secara keseluruhan dimana sistem akuntansi pemerintah daerah merupakan sistem yang mampu mengolah data keuangan, pencatatan, sampai dengan hasil pelaporan keuangan yang menghasilkan informasi yang jelas yang dapat digunakan sebagai dasar dalam pengambilan keputusan tentang perencanaan, pelaksanaan, dan pelaporan pertanggungjawaban pemerintah daerah yang akan mengasilkan laporan keuangan yang baik, dimana hasil maupun opini dari laporan keuangan merupakan prestasi kerja dari pengelola keuangan pada suatu Pemerintah Daerah

Selain memperhatikan faktor Sumber Daya Manusia yang unggul hal lain yang perlu diperhatikan juga yaitu faktor yang berhubungan dengan kinerja untuk mengukur produktivitas kerja yang ada seperti semangat kerja yang dibangun harus berdasarkan situas kondisi budaya yang ada dan harus dibangun dengan semangat motivasi yang positif, artinya tidak bertentangan dengan lingkungan dimana para pegawai melaksanakan pekerjaannya dan tidak bertentangan dengan semangat kerja individual. Jika semangat kerja dapat terbangun maka lingkungan kerjapun akan kondusif dan berpengaruh langsung terhadap kinerja yang ada.

\section{Tanggung jawab}

Tanggung jawab bersumber atau lahir atas penggunaan fasilitas dalam penerapan kemampuan tiap orang untuk menggunakan hak atau melaksanakan kewajibannya. Dengan demikian tanggung jawab merupakan pelaksanaan kewajiban dan setiap penggunaan hak, baik yang dilakukan secara tidak memadai maupun yang dilakukan secara memadai. Pada dasarnya, tetap harus disertai dengan pertanggung jawaban, demikian pula dengan pelaksanaan kekuasan.

Kinerja dalam tanggungjawab pegawai merupakan pengukuran tingkat pencapaian atas tujuan, visi, dan misi organisasi sebagai fungsi dari interaksi antara kemampuan, motivasi, dan keinginan pegawai. Dalam konteks penelitian yang akan dilakukan, maka analisis kinerja merupakan proses pengumpulan informasi tentang bagaimana tingkat kemampuan pencapaian hasil kerja yang dilakukan oleh pegawai di Badan Pengelolaan Keuangan dan Asset Daerah (BPKAD) Kabupaten Jeneponto dalam melaksanakan tugas pokok dan fungsinya sesuai dengan visi dan misi akan tercapai.

Umumnya sebuah organisasi menginginkan agar para pegawai berhasil melaksanakan tugas pekerjaan sesuai dengan tujuan organisasi. Baik buruknya kinerja pegawai dapat disebabkan oleh kemampuan pimpinan dalam mempengaruhi pegawai untuk bekerja sesuai dengan harapan organisasi. Kegiatan mempengaruhi pegawai dapat disebut dengan motivasi kerja. Jadi semakin besar motivasi yang dimiliki pegawai dalam melaksanakan tugas pekerjaannya semakin besar kinerja pegawai yang dapat dicapai

\section{KESIMPULAN DAN SARAN}

Kinerja Pegawai dalam Mendukung Pelaksanaan Tugas Pokok Badan Pengelola Keuangan dan Asset Daerah Kabupaten Jeneponto.

a. Kualitas kerja; bahwa kualitas kerja dalam kedisiplinan dan inisiatif pegawai 
masih perlu untuk ditingkatkan karena masih adanya pegawai terlambat datang dan cepat pulang kemudian Kualifikasi Pegawai, masih ada belum sesuai dengan kualifikasi pekerjaan Penguasaan Teknologi Masih terdapat pegawai yang belum menguasai penggunaan Ilmu Teknologi (IT) dengan baik Pengetahuan tentang Tupoksi Para pegawai sudah mengetahui tugas pokok dan fungsinya masing-masing

b. Kerjasama; pegawai melaukan bekerjasama dengan baik dalam Mendukung Pelaksanaan Tugas Pokok Badan Pengelola Keuangan dan Asset Daerah Kabupaten Jeneponto

c. Loyalitas; secara umum kami liat pegawai pada kantor di Badan Pengelolaan Keuangan dan Asset Daerah (BPKAD) sudah loyal terhadap organisasi dan pimpinan Dan selain loyalitas tentu beberapa faktor yang berhubungan dengan kinerja dan produktivitas diantaranya semangat kerja, tingkat pendidikan, keterampilan, sikap dan etika, motivasi, dan disiplin kerja

d. Tanggung jawab; Tanggungjawab pegawai pun diperhatikan dan diperlihatkan oleh pegawai dalam membentuk kinerja Badan Pengelolaan Keuangan dan Asset Daerah (BPKAD) kabupaten jeneponto itu terlihat dari sikap dan etika yang baik pegawai dengan latar belakang pendidikan yang tinggi dan keterampilan yang

Upaya meningkatkan kinerja pegawai badan pengelola keuangan dan asset daerah; (a). Kemampuan Kinerja Pegawai atas Laporan Keuangan (CaLK) mengacu pada Standar, yaitu; mampu memahami Tujuan Sistem Akuntansi Pemerintah Daerah yaitu pencatatan, pemerosesan dan pelaporan transaksi keuangan yang konsisten berdasarkan standar dan praktek akuntansi yang diterima secara umum dan dan menyediakan informasi yang dapat dipercaya mengenai posisi keuangan suatu instansi dan pemerintah secara keseluruhan; untuk menyediakan informasi keuangan yang berguna untuk tujuan perencanaan, pengelolaan, dan pengendalian kegiatan dan keuangan pemerintah secara efisien. (b) Peningkatan Kompetensi Pegawai, yaitu; meningkatakan kompetensi pegawai yang dilakukan dapat memperdalam dan memperluas kemampuan kerja, dan , SKPD harus memiliki SDM yang berkompeten, yang didukung dengan latar belakang pendidikan yang sesuai, sering mengikuti pendidikan dan pelatihan serta mempunyai pengalaman di bagian keuangan. (c) Tunjangan Kesejahteraan Pegawai, yaitu; memberikan tambahan penghasilan kepada pegawai negeri sipil daerah berdasarkan pertimbangan yang obyektif dengan memperhatikan kemampuan keuangan daerah dan memperoleh persetujuan DPRD sesuai dengan ketentuan peraturan perundang-undangan kemudian tambahan penghasilan yang diberikan kepada pegawai negeri sipil dalam rangka peningkatan kesejahteraan pegawai adalah berdasarkan prestasi kerja, tempat bertugas, kondisi kerja dan kelangkaan profesi.

Berdasarkan hasil penelitian yang telah dilakukan oleh peneliti, peneliti memberikan saran untuk meningkatkan Kinerja Pegawai dalam Mendukung Pelaksanaan Tugas Pokok Badan Pengelola Keuangan dan Asset Daerah Kabupaten Jeneponto sehingga dapat terwujud apa yang kita semua cita-citakan yaitu tata kelola kepemerintahan yang baik (good governance). Saran tersebut adalah sebagai berikut :

a. Agar hasil pekerjaan dapat menghasilkan kualitas pekerjaan yang terbaik maka perlu diadakannya peningkatan kualitas sumber daya manusia seperti langkah kongkritnya yaitu memberikan pelatihanpelatihan khusus secara rutin seperti pelatihan petugas pengelolaan keuangan, pelatihan kepemimpinan, dan pelatihan lainnya yang berhubungan dengan peningkatan kompetensi pegawai. Hal tersebut bertujuan agar kemampuan atau skill yang dimiliki oleh setiap pegawai meningkat dan dapat menghasilkan output pekerjaan yang baik dan maksimal demi tercapainya sebuah tujuan yang sebelumnya telah ditentukan.

b. Agar hasil pekerjaan dapat menghasilkan kuantitas pekerjaan yang terbaik maka perlu diadakannya motivasi dan pemberian punish and reward agar para pegawai terpacu untuk lebih meningkatkan kinerjanya dan Pemberian sanksi kepada pegawai yang malas- 
malasan dalam menyelesaikan pekerjaan sehingga dapat meningkatkan kedisiplinan pegawai.

\section{REFERENSI}

A.Dale, Timpe.,2003. Seri Manajemen Sumber Daya Manusia Memotivasi Pegawai. Jakarta., Penerbit: PT. Alex Media Komputindo.

Ambar Teguh. Sulistiyani, 2003. Kinerja. Bandung, Penerbit: Rosda Karya. Anwar Prabu A.A, Mangkunegara, 2007. Manajemen Sumber Daya Manusia. Penerbit: Remaja Rosdakarya, Bandung.

Arifin, Johar dan A. Fauzi, 2007. Aplikasi Exel dalam Aspek Kuantitatif Manajemen Sumber Daya Manusia. Jakarta.Penerbit: PT. Elex Media Komputindo.

Arikunto.suharsini, 2002. Prosedur Penelitian, Jakarta: Rineka Cipta. , 2006. Prosedur Penelitian Suatu Pendekatan Praktek.Jakarta: PT. Renika Cipta

Buchanan, dalam Garry Dessier, 1992. Organization Theory. New York. Prentice Hall.

Darise, Nurlan, 2009. Pengelolaan Keuangan pada Satuan Kerja Perangkat Daerah. PT. Indeks.Jakarta

Dharma, Surya., 2005. Manajemen Kinerja. Yogyakarta: PustakaPelajar Dewi,

Ike Janita., 2006. Maximum Motivation. Yogyakarta : Santusta

Elliot. J., 1993. Action Research For Education Change. Philadelphia: Open University.

Feigenbaum A.V., 1991, Total Quality Control, New York. McGraw-Hill.

Gaspersz, Vincent, 2005. Total Quality Management. Jakarta: PT. Gramedia Pustaka Utama

Gibson, Ivancevich, Donnelly., 2006. Organization Behavior Structure Prosses (INTERNATIONAL EDITION).Jakarta: Binarupa Aksara.

Gibson, James,L. 2000. Organisasi, Perilaku, Struktur dan Proses. Edisi ke-5 Cetakan ke-3. Jakarta: Penerbit Erlangga

Hamid, Edy Suandi dan Malian, Sobirin., 2004. Memperkokoh Otonomi Daerah
Kebijakan Evaluasi dan Saran, Cetakan ke-1. Yogyakarta, UII Press.

Handoko, et. al., 1994. Manajemen Personalia dan Sumber Daya Manusia, Edisi ke2, Yogjakarta. Penerbit: BPFE.

Handoko, T. H., 1995. Manajemen Sumber Daya Manusia. Jakarta, Penerbit: Bumi Aksara.

Hasibuan, Malayu, 2008. Manajemen Sumber Daya Manusia. Jakarta, Penerbit: BumiAksara.

Juran, J.M. 1989. Juran on Leadership for Quality, The Free Press, MacMillan,Inc. E.

Kartono, Kartini., 2003. Pemimpin daerah. Jakarta, Penerbit: Rajawali.

Mardiasmo,.2002. Otonomi dan Manejemen Keuangan Daerah,. Penerbit ANDI, Yokyakarta.

Mink, 2003. Seri Manajemen Sumber Daya Manusia (Kinerja/Performance). Jakarta: PT.Elik Media Koputindo.

Mujiono, Imam. 2002. Kepemimpinan dan Keorganisasian. Yogyakarta: UII Press.

Sariyathi, 2003. Kepe-mimpinan Mutu. Jakarta, Pustaka Binaman Pressindo. Purbacaraka, 1998. Perihal Kaedah Hukum, Bandung: Citra Aditya.

Rachmawati, Ike Kusdiyah, 2008. Manajemen Sumber Daya Manusia. Yogyakarta, Penerbit: CV. Andi Offset.

Rivai, Veithzal. 2006. Kepemimpinan dan Perilaku Organisasi Edisi 2. Jakarta, Penerbit: Raja Grafindo Persada.

Ridwan Halim, 2001. Tindak Pidana Pendidikan: Suatu Tinjauan filosofis Edukatif Jakarta: Ghalia Indonesia.

Robbins, Stephen P.,2009. Perilaku Organisasi. Edisi Bahasa Indonesia, Jilid I dan II. Jakarta, Penerbit: Prinhalindo.

Saleh \& Rochmansja,. 2010,.Pengelolaan Keuangan dan Asset Daerah. Fokus Media,. Bandung.

Sugiyono.,2010. Statistik Untuk Penelitian. Bandung, Penerbit:Alfabeta.

Sutrisno, Edy,. 2010. Manejemen Sumber Daya Manusia,. Prenada Media Grup.Jakarta

Prawirosentono,Suyadi., 2004. Filosofi Baru Tentang Manajemen Mutu Terpadu Total Quality Management Abad 21: 
Studi Kasus dan Analisis. Penerbit: PT. Bumi Aksara, Jakarta.

Tead, Terry, Hoyt Dalam Kartono, 2003. Beyond Leadership (12 Konsep Kepemimpinan).Jakarta, Penerbit: PT. Elek Media Komputindo.

Thoha, Miftah, 2013. Perilaku Organisasi Konsep Dasar dan Aplikasinya. Jakarta, Raja Grafindo Persada.

Tika, 2006,. Budaya Organisasi dan Peningkatan Kinerja Perusahaan,. PT. Bumi Aksara,. Jakarta.

West, M.A. 2002. Mengembangkan Kreativitas dalam Organisasi, Edisi Pertama. Yogyakarta, Penerbit: Kanisius.

Wungu \& rotoharjo, 2003. Tingkatkan Kinerja Perusahaan Anda Dengan Merit Sistem. Jakarta, Penerbit: Raja Grafindo Pustaka

Zuriah, Nurul, 2007. Metodologi Penelitian Sosial Dan Pendidikan. Teori Aplikasi, Cetakan kedua. Jakarta, PT. Bumi Aksara.

Dokumen

Undang-undang No. 32 Tahun 2004 tentang Pemerintah Daerah.

Undang-Undang nomor 5 Tahun 2014 tentang Aparatur Sipil Negara pasal 23

Pengertian kinerja berdasarkan Permendagri No. 21 Tahun 2011

Peraturan Pemerintah No. 58 Tahun 2005 Keuangan daerah

Pengelolaan keuangan daerah sesuai PP No. 58 Tahun 2005 pasal 1 ayat 6

Permendagri No. 21 Tahun2011 tentang Pedoman Pengelolaan Keuangan Daerah bab I pasal 1 ayat 8 